УДК 378.011

DOI:

Олександра Чубрей, кандидат історичних наук, доцент, дочент кафедри економічної географії та екологічного менеджменту Чернівеиького національного університету імені Ю. Федьковича

\title{
РІВНІ ПІДГОТОВЛЕНОСТІ МАЙБУТНІХ ВЧИТЕЛІВ ГЕОГРАФІЇ ДО ПРОФЕСІЙНОӤ ДІЯЛЬНОСТІ НА ЗАСАДАХ КОМПЕТЕНТНІСНОГО ПІДХОДУ
}

У статті розкрито рівні підготовленості майбутніх вчителів географії за кожною складовою підготовленості до професійної діяльності на засадах компетентнісного підходу. До складових підготовленості майбутніх вчителів географії до професійної діяльності віднесено автопсихологічну, самоорганізаційну, рефлексивну, самоосвітню, організаторську, лідерську, технологічну. На основі критеріїв та відповідних показників встановлено рівні підготовленості майбутніх вчителів географії: низький, достатній, середній та високий.

Ключові слова: майбутні вчителі географії; рівні підготовленості; складові підготовленості; авто психологічна; самоорганізаційна; рефлексивна; самоосвітня; організаторська; лідерська; технологічна

תim. 5.

Olexandra Chubrey, Ph.D.(History), Associate Professor of the Economic Geography and Environmental Management Department Chernivtsi Yuriy Fedkovych National University

\section{LEVELS OF PREPARATION OF FUTURE GEOGRAPHY TEACHERS TO PROFESSIONALACTIVITIES ON THE BASIS COMPETENCE APPROACH}

The article describes the level of preparation of future teachers of geography for each component of preparation for professional activity on the basis of competence approach. Auto-psychological, self-organizing, reflexive, selfeducational, organizational, leadership, and technological components are included in the components of the future geography teachers' preparation for professional activity. Based on the criteria and relevant indicators, the preparedness levels of future geography teachers are set to be low, sufficient, medium and high.

On a general scale, a low level indicates that the future geography teacher is completely unprepared for a professional activity based on a competent approach. In these circumstances, such a teacher will feel insecure, inadequate to respond to the challenges that will arise in professional activity and professional development, and will require constant methodological assistance and motivation. On a general scale, a sufficient level of preparedness indicates a certain minimum admissibility of the future teacher of geography for professional activity on the basis of a competence approach. In these circumstances, such a teacher will often be able to feel confident, sometimes adequately responding to challenges that will arise in professional activity and professional development. However, such teacher will sometimes need methodological help and motivation. The average level of preparedness indicates that the future geography teacher is appropriately prepared for professional activity based on a competency approach. In these circumstances, such teacher can always feel confident, almost constantly adequately respond to the challenges that will arise in professional activity and professional development. Methodological help and motivation for such a teacher will be needed only sometimes.

High level of preparedness indicates the effective preparation of a future geography teacher for professional activity based on a competence approach. In these circumstances, such teacher will always feel confident, able to constantly and adequately respond to the challenges that will arise in professional activity and professional development. Methodical help and motivation is not needed for a teacher.

Keywords: future teachers of geography; levels of readiness; components of readiness; auto-psychological; self-organizing; reflexive; self-educational; organizational; leadership; technological.

П остановка проблеми. Формування системи професійної підготовки вчителів у кожній країні має історичний характер розвитку. Напрямки, зміст, форми, засоби такої підготовки зумовлені соціальноекономічними, історико-культурними чинниками, загальнонаціональними і світовими традиціями. Саме тому розвиток професійної підготовки майбутніх вчителів географії вплетений у контекст розвитку загальноєвропейської і світової загальноосвітньої педагогічної освіти та внутрішньодержавних соціально-економічних процесів.

Аналіз основних досліджень і публікацій. Характеристика рівнів підготовленості майбутніх вчителів географії до професійної діяльності на засадах компетентнісного підходу стала предметом досліджень багатьох українських 
науковців, серед яких В. Багрій [1], С. Гончаренко [2], О. Іонова [3], В. Танська [ 4], Т. Фурман [5] та ін.

Проте, в сучасних умовах аналіз рівнів підготовленості майбутніх вчителів географії за кожною складовою підготовленості до професійної діяльності на засадах компетентнісного підходу не отримало належної уваги, що і зумовлює актуальність нашого дослідження.

Мета статті - проаналізувати рівні підготовленості майбутніх вчителів географії за кожною складовою підготовленості до професійної діяльності на засадах компетентнісного підходу.

Виклад основного матеріалу дослідження. Для забезпечення їх ефективного відбору насамперед необхідно визначити сутність понять “критерій”, “показник” та “рівень”.

Так, у психолого-педагогічній літературі поняття “критерій” розглядається як:

- “засіб, оцінка, мірило чогось” (С. Гончаренко) [2];

- стандарт за яким можна оцінити реальне педагогічне явище (процес) або порівняти його 3 еталоном" [1].

Виділення й обгрунтування критеріїв оцінювання досліджуваного феномену повинно базуватись на певних вимогах, до яких науковці відносять:

- формулювання критеріїв повинно бути максимально ясним, точним й коротким, при цьому, вони мають вимірювати те, що бажає оцінити дослідник (О. Іонова) [3].

У сучасних дослідженнях, поняття “критерій” тісно пов'язують 3 поняттям “показник”.

Так, на думку Т. Фурман, кожен критерій знаходить своє вираження у конкретних показниках.

Поняття “показник” визначається як:

- “ознака чого-небудь; явище або подія, на підставі яких можна робити висновки про перебіг якого-небудь процесу; кількісна характеристика властивостей процесу" [5];

- найбільш загальна властивість досліджуваного феномену, що може безпосередньо спостерігатися та підлягає вимірюванню (Т. Фурман) [5, 175];

- один з складових критерію, що кількісно або якісно виражає одну зі сторін стану досліджуваного об'єкту, процесу та явища (В. Танська) [4, 12].

Поняття "рівень” визначається як “ступінь якості, величина досягнута у чому-небудь; ступінь чиєїсь освіти, культури, підготовки”. Відтак, рівень виступає як ступінь прояву показників за відповідними критеріями.

На основі узагальнення зазначених критеріїв та відповідних показників було встановлено рівні підготовленості майбутніх вчителів географії: низький, достатній, середній та високий.

Охарактеризуймо рівні підготовленості майбутніх вчителів географії за кожною складовою підготовленості до професійної діяльності на засадах компетентнісного підходу окремо.

Так, низький рівень автопсихологічної складової підготовленості характеризується необізнаністю майбутнього вчителя географії про зміст і показники автопсихологічної компетентності. Прагнення майбутнього вчителя географії до пізнання самого себе не проявляються. Самооцінка майбутнього вчителя географії часто неадекватна. Рівень самоприйняття та самоповаги майбутнього вчителя географії дуже низький. Автопсихологічна компетентність не сформована.

Достатній рівень автопсихологічної складової підготовленості характеризується певним проявом обізнаності майбутнього вчителя географії про зміст і показники автопсихологічної компетентності та і1і вплив на ефективність майбутньої професійної діяльності. Уміння майбутнього вчителя географії у галузі самодіагностики, особистісної саморегуляції, й самовдосконалення виявляються лише частково. Автопсихологічна компетентність сформована на мінімально допустимому рівні.

Середній рівень автопсихологічної складової підготовленості характеризується прагненням майбутнього вчителя географії здобути психологічні знання, щоби на їх основі забезпечити реалізацію свого творчого потенціалу, самоактуалізацію й самореалізаціюупрофесійній діяльності не завжди проявляється. Автопсихологічна компетентність сформована на середньому рівні.

Високий рівень автопсихологічної складової підготовленості характеризується грунтовною обізнаністю майбутнього вчителя географії про зміст і показники автопсихологічної компетентності та їі вплив на ефективність майбутньої професійної діяльності. Здатність майбутнього вчителя географії розраховувати на власні сили має зразковий характер. Автопсихологічна компетентність сформована на зразковому рівні.

Низький рівень самоорганізаційної складової підготовленості характеризується слабким проявом вмінь майбутнього вчителя географії здійснювати саморегуляцію власної діяльності та емоційної сфери, економно розподіляти власні сили та засоби й планувати свою діяльність і час на професійний розвиток. Самоорганізаційна компетентність не сформована. 

НАЗАСАДАХ КОМПЕТЕНТНІСНОГОПДХОДУ

Достатній рівень самоорганізаційної складової підготовленості характеризується певним проявом вмінь майбутнього вчителя географії здійснювати саморегуляцію власної діяльності та емоційної сфери. Самоорганізаційна компетентність сформована на мінімально допустимому рівні.

Середній рівень самоорганізаційної складової підготовленості характеризується частим проявом вмінь майбутнього вчителя географії здійснювати саморегуляцію власної діяльності та емоційної сфери, економно розподіляти власні сили та засоби, планувати свою діяльність і час на професійний розвиток. Здатність майбутнього вчителя географії до критичності в оцінювання результатів своєї праці проявляється завжди. Самоорганізаційна компетентність сформована на середньому рівні.

Високий рівень самоорганізаційної складової підготовленості характеризується здатністю майбутнього вчителя географії керувати собою, здісйнювати самоконтроль й самодисципліну та критично оцінювати результати своєї праці яскраво виражені і проявляються завжди. Самоорганізаційна компетентність сформована на зразковому рівні.

Низький рівень рефлексивної складової підготовленості характеризується слабким проявом уявлення майбутнього вчителя географії про образ власного “Я”, власні вчинки та відносини 3 колегами і учнями, внутрішній світ інших та психологічні детермінанти їх діяльності й поведінки. Уміння майбутнього вчителя географії виявляти та аналізувати допущені помилки, розкривати психолого-педагогічні причини їх виникнення, забезпечувати самоаналіз, самоконтроль й самооцінку у педагогічній діяльності не проявляються зовсім. Рефлексивна компетентність не сформована.

Достатній рівень рефлексивної складової підготовленості характеризується певними уявленнями майбутнього вчителя географії про образ власного “Я”, власні вчинки, відносини 3 колегами і учнями, внутрішній світ інших та психологічні детермінанти їх діяльності й поведінки. Усвідомлення майбутнім вчителем географії значущості професійної діяльності для себе й суспільства проявляється майже завжди. Рефлексивна компетентність сформована на мінімально допустимому рівні.

Середній рівень рефлексивної складової підготовленості характеризується належно сформованими уявленнями майбутнього вчителя географії про образ власного “Я”. Обізнаність майбутнього вчителя географії щодо рольових функцій та організацію взаємодії у колективі, процеси актуалізації особистості, реалізацію іiі рефлексивних здібностей, осмислення й подолання стереотипів мислення має розвинений характер. Рефлексивна компетентність сформована на середньому рівні.

Високий рівень рефлексивної складової підготовленості характеризується зразковими уявленнями майбутнього вчителя географії про відносини з колегами і учнями, внутрішній світ інших та психологічні детермінанти їх діяльності й поведінки. На цьому рівні майбутній вчитель географії повністю усвідомлює значущість професійної діяльності для себе й суспільства. Рефлексивна компетентність сформована на зразковому рівні.

Низький рівень самоосвітньої складової підготовленості характеризується відсутністю у майбутнього вчителя географії уявлення про методи пізнання й володіння прийомами самонавчання. Обізнаність майбутнього вчителя географії про планування, організацію та реалізацію самоосвітньої діяльності має значні прогалини. Критичне ставлення до будь-якої отриманої інформації відсутнє. Самоосвітня компетентність не сформована.

Достатній рівень самоосвітньої складової підготовленості характеризується здатністю майбутнього вчителя географії розробляти програми самоосвіти відповідно до власних потреб і вимог професії, коригувати результати, отримані під час самоосвіти та представляти, обгрунтовувати й захищати їх проявляються майже завжди. Самоосвітня компетентність сформована на мінімально допустимому рівні.

Середній рівень самоосвітньої складової підготовленості характеризується критичним ставленням до будь-якої отриманої інформації. Майбутній вчитель географії спрямований на постійну діяльність й саморозвиток. Відповідальність за власну самоосвітню діяльність та їі результати майбутній вчитель географії бере на себе. Самоосвітня компетентність сформована на середньому рівні.

Високий рівень самоосвітньої складової підготовленості характеризується зразковими уявленнями майбутнього вчителя географії про методи пізнання, володіння прийомами самонавчання. Прагнення майбутнього вчителя географії задовольнити індивідуальні й соціальні потреб пізнання дійсності, досягти високого рівня професійної компетентності й бажання протистояти невизначеностям професійної діяльності та життя яскраво виражені. Самоосвітня компетентність сформована на зразковому рівні. 

НАЗАСАДАХКОМПЕТЕНТНІСНОГОПІХОДУ

\begin{abstract}
Низький рівень організаторської складової підготовленості характеризується слабкими знаннями щодо організаторської діяльності вчителя географії. Толерантність майбутнього вчителя географії розвинена слабко. Організаторська компетентність не сформована.

Достатній рівень організаторської складової підготовленості характеризується певними знаннями щодо організаторської діяльності вчителя географії. Організаторська компетентність сформована на мінімально допустимому рівні.

Середній рівень організаторської складової підготовленості характеризується умінням майбутнього вчителя географії організувати учнівський колектив та взаємовідносини у ньому, працювати з активом класу та координувати його дії, своєчасно передавати організаторські функції та делегувати повноваження, надихати учнів та вирішувати конфлікти, які виникають у екскурсіях та походах проявляються завжди. Організаторська компетентність сформована на середньому рівні.

Високий рівень організаторської складової підготовленості характеризується грутовними знаннями щодо організаторської діяльності вчителя географії. Толерантність майбутнього
\end{abstract} вчителя географії має зразковий характер.

Низький рівень лідерськоӥ складової підготовленості характеризується невпевненість і низькою стресостійкістю майбутнього вчителя географії. Емпатія, необхідна для підтримки учнів у стресових ситуаціях, які можуть виникнути у походах та екскурсіях проявляється дуже рідко. Комунікативність та здатність активно слухати й розуміти невербальну лексику не проявляються зовсім. Лідерська компетентність не сформована.

Достатній рівень характеризується умінням майбутнього вчителя географії вести за собою колектив учнів й особистим прикладом надихати учнів та встановити партнерство в учнівському колективі у походах та екскурсіях певним чином проявляються. Емпатія, необхідна для підтримки учнів у стресових ситуаціях, які можуть виникнути у походах та екскурсіях проявляється не часто, але на достатньому рівні. Лідерська компетентність сформована на мінімально допустимому рівні.

Середній рівень лідерської складової підготовленості характеризується впевненістю та певною стресостійкістю майбутнього вчителя географії. Комунікативність та здатність активно слухати й розуміти невербальну лексику яскраво проявляються. Лідерська компетентність сформована на середньому рівні.

Високий рівень лідерської складової підготовленості характеризується умінням майбутнього вчителя географії вести за собою колектив учнів й особистим прикладом надихати учнів та встановити партнерство в учнівському колективі у походах та екскурсіях мають зразковий характер. Емпатія, необхідна для підтримки учнів у стресових ситуаціях, які можуть виникнути у походах та екскурсіях розвинена зразково. Лідерська компетентність сформована на зразковому рівні.

Низький рівень технологічної складової підготовленості характеризується значними прогалинами в уявленнях майбутнього вчителя географії про алгоритми та їх роль для професійній діяльності та розумінні сутності технологічного підходу при викладання географії. Технологічна компетентність не сформована.

Знання майбутнього вчителя географії суті, змісту та особливостей технологій та вміння їх впроваджувати у власну професійну діяльність та професійний розвиток слабо розвинені на достатньому рівні. Технологічна компетентність сформована на мінімально допустимому рівні.

Середній рівень технологічної складової підготовленості характеризується належними уявленнями майбутнього вчителя географії про алгоритми та їх роль для професійній діяльності та розумінні сутності технологічного підходу при викладання географіі. Технологічна компетентність сформована на середньому рівні.

Високий рівень технологічної складової підготовленості характеризується зразковими уявленнями майбутнього вчителя географії про алгоритми та їх роль для професійній діяльності, знаннями та вміннями розкласти на складові процес досягнення бажаного освітнього результату, прогнозувати і проектувати власну діяльність у технологічному середовищі, яке знаходиться в умовах постійних змін носять зразковий характер. Технологічна компетентність сформована на зразковому рівні.

Висновки 3 даного дослідження. В ході дослідження нами охарактеризовано рівні підготовленості майбутніх вчителів географії за кожною складовою підготовленості до професійної діяльності назасадах компетентнісного підходу окремо.

До складових підготовленості майбутніх вчителів географії до професійної діяльності на засадах компетентнісного підходу нами віднесено автопсихологічну, самоорганізаційну, рефлексивну, самоосвітню, організаторську, лідерську, технологічну. На основі критеріїв та відповідних показників встановлено рівні підготовленості майбутніх вчителів географії: низький, достатній, середній та високий. 
За загальною шкалою низький рівень свідчить про цілковиту непідготовленість майбутнього вчителя географії до професійної діяльності на засадах компетентнісного підходу. У зазначених умовах такий вчитель буде почувати себе невпевнено, неадекватно реагувати на виклики, які виникатимуть у професійній діяльності й професійному розвитку, а також потребуватиме постійної методичної допомоги та мотивації.

За загальною шкалою достатній рівень підготовленості свідчить про певну мінімально допустиму підготовленість майбутнього вчителя географії до професійної діяльності на засадах компетентнісного підходу. У зазначених умовах такий вчитель часто зможе почувати себе впевнено, іноді адекватно реагувати на виклики, які виникатимуть у професійній діяльності й професійному розвитку. Проте такий вчитель іноді потребуватиме методичної допомоги та мотивації.

За загальною шкалою середній рівень підготовленості свідчить про відповідну підготовленість майбутнього вчителя географії до професійної діяльності на засадах компетентнісного підходу. У зазначених умовах такий вчитель зможе завжди почувати себе впевнено, майже постійно адекватно реагувати на виклики, які виникатимуть у професійній діяльності й професійному розвитку. Методична допомога та мотивація такому вчителю буде потрібна лише іноді.

За загальною шкалою високий рівень підготовленості свідчить про ефективну підготовленість майбутнього вчителя географії до професійної діяльності на засадах компетентнісного підходу. У зазначених умовах такий вчитель завжди почуватиме себе впевнено, зможе постійно й адекватно реагувати на виклики, які виникатимуть у професійній діяльності й професійному розвитку. Методична допомога та мотивація такому вчителю не потрібна.

Перспективи подальших досліджень полягають в аналізі організаційно-педагогічних умов підготовки майбутніх вчителів географії до професійної діяльності на засадах компетентнісного підходу.

\section{ЛІТЕРАТУРА}

1. Багрій В.Н. Критерії та рівні сформованості професійних умінь майбутніх соціальних педагогів. Збірник наукових праць Хмельницького інституту соціальних технологій Університету "Україна", 2012. URL: http://nbuv.gov.ua/j-pdf/ Znpkhist_2012_6_4.pdf.

2. Гончаренко С.У. Педагогічні дослідження: методологічні поради молодим науковцям. Вінниця, 2008. 278 с.

3. Ионова О.Н. Теоретические аспекты формирования информационной компетентности взрослых. Вестник Новгородского государственного университета им. Ярослава Мудрого, 2006. №39. C. $84-85$.

4. Танська В.В. Підготовка майбутнього вчителя біології до екологічної освіти старшокласників : автореф. дис. на здобуття наук. ступеня канд. пед. наук : спец. 13.00.04 “теорія і методика професійної освіти”. Житомир, 2006. 20 с.

5. Фурман Т.Ю. Організація та зміст педагогічного експерименту 3 формування професійної компетентності майбутніх фахівців у галузі економіки та підприємництва. Наук. вісн. Ужгород. нац. ун-ту. Серія "Педагогіка. Соціальна робота”, 2011. № 22. С. 174-177.

\section{REFERENCES}

1. Bahrii, V.N. (2012). Kryterii ta rivni sformovanosti profesiinykh umin maibutnikh sotsialnykh pedahohiv [Criteria and levels of development of professional skills of future social educators]. Collection of scientific works of Khmelnitsky Institute of Social Technologies of the University of Ukraine. Available at: http:// nbuv.gov.ua/j-pdf/Znpkhist_2012_6_4.pdfю [in Ukrainian].

2. Honcharenko, S.U. (2008). Pedahohichni doslidzhennia: metodolohichni porady molodym naukovtsiam [Pedagogical research: methodological advice to young scientists]. Vinnytsia, 278 p. [in Ukrainian].

3. Ionova, O.N. O (2006). Teoreticheskie aspekty formirovaniya informatsionnoy kompetentnosti vzroslykh [Herald of Novgorod State University of Yaroslav Mudrvy]. No.39. pp. 84-85. [in Ukrainian].

4. Tanska, V.V. (2006). Pidhotovka maibutnoho vchytelia biolohii do ekolohichnoi osvity starshoklasnykiv [Preparation of future biology teacher for environmental education of high school students]. Extended abstract of candidate's thesis. Zhytomyr, 20 p. [in Ukrainian].

5. Furman, T.Iu. (2011). Orhanizatsiia ta zmist pedahohichnoho eksperymentu $\mathrm{z}$ formuvannia profesiinoi kompetentnosti maibutnikh fakhivtsiv $u$ haluzi ekonomiky ta pidpryiemnytstva [Organization and content of a pedagogical experiment on the formation of professional competence of future specialists in the field of economics and entrepreneurship]. Scientific herald of Uzhhorod National university, the series "Pedagogy. Social Work”. No. 22, pp. 174-177. [in Ukrainian].

Стаття надійшла до редакції 04.09.2019 